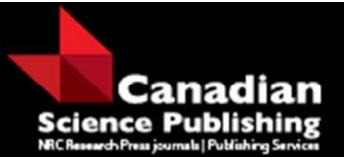

Canadian Journal of Forest Research

Revue canadienne de recherche forestière

\title{
Effects of Paenibacillus polymyxa inoculation and different soil nitrogen treatments on lodgepole pine seedling growth
}

\begin{tabular}{|r|l|}
\hline Journal: & Canadian Journal of Forest Research \\
\hline Manuscript ID & cjfr-2015-0456.R3 \\
\hline Manuscript Type: & Article \\
\hline Date Submitted by the Author: & 15 -Mar-2016 \\
\hline Complete List of Authors: & $\begin{array}{l}\text { Yang, Henry; University of British Columbia, Forest and Conservation } \\
\text { Sciences } \\
\text { Puri, Akshit; University of British Columbia, Forest and Conservation } \\
\text { Sciences } \\
\text { Padda, Kiran Preet; University of British Columbia, Forest and Conservation } \\
\text { Sciences } \\
\text { Chanway, Christopher; UBC, Forest Sciences }\end{array}$ \\
\hline Keyword: & $\begin{array}{l}\text { Lodgepole pine, Biological nitrogen fixation, Plant growth promotion, } \\
\text { Endophytic diazotroph, <i }>\text { Paenibacillus polymyxa </i> }\end{array}$ \\
\hline
\end{tabular}


1 Effects of Paenibacillus polymyxa inoculation and different soil nitrogen 2 treatments on lodgepole pine seedling growth

3 Authors: Henry Yang $^{1}$, Akshit Puri ${ }^{1, *}$, Kiran Preet Padda ${ }^{1}$ and Chris P Chanway ${ }^{1}$

$4 \quad{ }^{1}$ Department of Forest and Conservation Sciences, Faculty of Forestry, University of British

5 Columbia, 3041-2424 Main Mall, Vancouver, BC V6T 1Z4, Canada

6 *Corresponding author. Tel.: +16048272175, Email address: akshit.puri@alumni.ubc.ca 


\section{$7 \quad$ Abstract}

8 An endophytic diazotroph, Paenibacillus polymyxa $\mathrm{P} 2 \mathrm{~b}-2 \mathrm{R}$, has been shown to colonize internal

9 tissues of lodgepole pine and stimulate seedling growth possibly through nitrogen (N) fixation in

10 an $\mathrm{N}$-limited environment. We evaluated the effects of different soil $\mathrm{N}$ concentrations on

11 lodgepole pine seedling growth after inoculation with $\mathrm{P} 2 \mathrm{~b}-2 \mathrm{R}$ in a year-long greenhouse study.

12 Seedlings were subjected to monthly application of a nutrient solution containing one of four soil

$13 \mathrm{~N}$ concentrations as $\mathrm{Ca}\left(\mathrm{NO}_{3}\right)_{2}\left(5 \%{ }^{15} \mathrm{~N}\right.$ label $): 0.0029,0.029,0.29$ and $2.9 \mu \mathrm{mol} / \mathrm{L}$, referred to as

14 'very low', 'low', 'medium' and 'high' soil $\mathrm{N}$ treatments, respectively. Foliar ${ }^{15} \mathrm{~N}$ atom\% excess

15 and foliar $\mathrm{N}$ content values of $\mathrm{P} 2 \mathrm{~b}-2 \mathrm{R}$ inoculated seedlings were not significantly different from

16 controls at any $\mathrm{N}$ treatment. Similarly, rhizospheric and endophytic population of P2b-2R did not

17 vary significantly across $\mathrm{N}$ treatments. Inoculation with $\mathrm{P} 2 \mathrm{~b}-2 \mathrm{R}$ resulted in seedling growth

18 inhibition during early stages of the experiment but by month twelve, inoculated seedlings from

19 the very low soil $\mathrm{N}$ treatment had accumulated $56.3 \%$ and $46.4 \%$ more root and shoot biomass

20 than controls, respectively. These results suggest that pine biomass stimulation by $\mathrm{P} 2 \mathrm{~b}-2 \mathrm{R}$ may

21 depend on soil $\mathrm{N}$ concentrations and that such growth stimulation may occur without providing

22 significant amounts of fixed $\mathrm{N}$.

23 Keywords: Lodgepole pine; Paenibacillus polymyxa; Biological nitrogen fixation; Plant growth

24 promotion; Endophytic diazotroph 


\section{Introduction}

26 Bacteria inhabiting the nutrient-rich microhabitat of rhizosphere, i.e., the soil immediately

27 surrounding plant roots, are known as rhizobacteria and are thought to benefit from the abundant

28 organic compounds released by roots as a ready source of nutrients. However, antagonistic

29 interactions such as parasitism (Cacciari et al. 1986) and competition with plants and other

30 microbes for these nutrients (Cocking 2003) may reduce the abundance of certain rhizobacterial

31 species including those known to exert positive effects on plant growth. In addition, a subset of

32 plant-colonizing bacteria and rhizobacteria may acquire these nutrients by colonizing plants

33 internally and stimulating plant growth in return. The term 'bacterial endophyte' is used to

34 describe a bacterium that colonizes internal plant tissues without inducing disease symptoms

35 (Hallmann et al. 1997; Azevedo et al. 2000). By occupying the plant interior, bacterial

36 endophytes may have a comparative advantage over rhizosphere-colonizing bacteria due to ready

37 access to continuous supplies of nutrients and an additional degree of protection from

38 competition and predation that likely occur outside plant roots (Hallmann et al. 1997).

39 The genus Paenibacillus was assigned to accommodate the former 'group 3' of the genus

40 Bacillus (Ash et al. 1993). In Latin paene means almost, and therefore the Paenibacillus is

41 almost a Bacillus. Paenibacillus polymyxa is a facultative anaerobe that is non-pathogenic and

42 form endospores (Lal and Tabacchioni 2009). It is found in environments such as plant roots,

43 soil, and marine sediment (Timmusk et al. 2005; Ravi et al. 2007). The wide range of potential

44 plant growth promoting characteristics of these bacteria includes the ability to fix $\mathrm{N}$ and produce

45 plant growth-promoting hormones and solubilize soil phosphorous (Lal and Tabacchioni 2009). 
$\mathrm{N}$-fixing bacteria are commonly referred to as diazotrophs and may be free-living or

47 occur in symbiotic associations. Free-living diazotrophs are self-sustaining and do not fix N

48 unless the amount of available $\mathrm{N}$ in their intermediate surroundings limit their growth. While the

49 general belief is that free-living diazotrophs do not contribute large quantities of fixed $\mathrm{N}$ to most

50 terrestrial ecosystems (Postgate 1998; Newton 2007), they are known to provide a biologically

51 significant proportion of fixed $\mathrm{N}$ in some tropical and temperate forest ecosystems (Cleveland et

52 al. 1999; Gehring et al. 2005; Reed and Martiny 2007). Significant amounts of N may be

53 provided by endophytic diazotrophs that do not induce macroscopic structural changes on or in

54 the plant hosts (Dobereiner et al. 1995; Malik et al. 1997).

In comparison with well-characterized $\mathrm{N}$ fixing systems in agricultural crops, studies of

56 diazotrophs within conifers, particularly those of commercial importance, have been scarce. In

57 North America, soil N deficiency is widespread and can limit the growth of tree seedlings in the

58 boreal forest and other ecosystems (Mahendrappa and Salonius 1982). However, the growth of

59 certain forest tree species such as lodgepole pine (Pinus contorta var. latifolia Engelm. ex S.

60 Watson) appears to be less affected by low soil $\mathrm{N}$ availability (Chapman and Paul 2012). The

61 ability of lodgepole pine to persist on $\mathrm{N}$-limited soils may relate to its physiological traits and

62 association with $\mathrm{N}$-fixing microbes living in rhizosphere. But according to Holl and Chanway

63 (1992), rhizospheric biological $\mathrm{N}$ fixation (BNF) contribute only 4\% to the total foliar $\mathrm{N}$ of

64 lodgepole pine, indicating that this process might not be able to enhance seedling growth in the

65 short term. A consortium of endophytic diazotrophic bacteria were isolated from internal tissues

66 of naturally regenerating lodgepole pine seedlings at a N-limited site near Williams Lake, BC,

67 Canada and used to test the hypothesis that such microorganisms could stimulate lodgepole pine

68 seedling growth through BNF (Bal et al. 2012). One strain, Paenibacillus polymyxa strain P2b- 
$692 \mathrm{R}$, was subsequently shown to be able to grow on $\mathrm{N}$-free media, to consistently display in vitro

70 nitrogenase (acetylene reduction) activity (Bal et al. 2012) and was found to harbour the nifH

71 gene that encodes nitrogenase (Anand and Chanway 2013c). When P2b-2R was re-introduced to

72 lodgepole pine, it was able to form persistent rhizospheric (Bal and Chanway 2012a) and

73 endophytic (Anand et al. 2013) populations, derive significant amounts of $\mathrm{N}$ from atmosphere

74 (79\%) and enhance seedling biomass (Anand et al. 2013). P. polymyxa P2b-2R was also tested

75 for its broad range host capability and was found to colonize, fix $\mathrm{N}$ and promote growth of

76 another tree species, western red cedar (Bal and Chanway 2012b; Anand and Chanway 2013b),

77 as well as the agricultural crops: corn (Puri et al. 2015; Puri et al. 2016b), canola (Puri et al.

78 2016a) and tomato (Padda et al. 2016). Using a green fluorescent protein (GFP) tagged

79 derivative of $\mathrm{P} 2 \mathrm{~b}-2 \mathrm{R}$ and confocal laser scanning microscopy, intracellular colonization of

80 lodgepole pine was also confirmed (Anand and Chanway 2013a). The significant contribution of

81 fixed $\mathrm{N}$ to seedlings and the concomitant biomass enhancement of lodgepole pine seedlings by

82 P2b-2R suggest that lodgepole pine may benefit from diazotrophic endophytes in N-deficient

83 soils. However, whether this mutualistic relationship continues to exist at higher soil $\mathrm{N}$

84 concentrations is unclear as high amounts of exogenous $\mathrm{N}$ are known to suppress in vitro

85 nitrogenase activity in other symbiotic systems (Dixon and Kahn 2004; Wang et al. 2013) and

86 can trigger specific metabolic and enzymatic activities in plants (Abellan et al. 1994), which may

87 result in reduced populations of endophytic diazotrophs (Fuentes-Ramirez et al. 1999; Munoz-

88 Rojas and Caballero-Mellado 2003).

The primary objective of this study was to determine if the amount of $\mathrm{N}$ fixed by $P$.

90 polymyxa $\mathrm{P} 2 \mathrm{~b}-2 \mathrm{R}$ treated lodgepole pine seedlings decreased in response to increasing soil $\mathrm{N}$

91 concentrations. To address this objective, we tested the following hypotheses: (i) rhizospheric 
92 and endophytic P2b-2R population sizes will decrease with increasing soil $\mathrm{N}$ concentrations

93 when inoculated in lodgepole pine, (ii) the percentage of $\mathrm{N}$ derived from the atmosphere

94 (\% Ndfa) by lodgepole pine seedlings inoculated with $\mathrm{P} 2 \mathrm{~b}-2 \mathrm{R}$ will decrease as soil $\mathrm{N}$

95 concentrations increase, and (iii) biomass of lodgepole pine seedlings treated with P2b-2R will

96 be greatest at the low soil $\mathrm{N}$ concentrations.

\section{Materials and methods}

\section{Seed and bacteria}

99 Lodgepole pine seeds were obtained from the BC Ministry of Forests Tree Seed Centre, Surrey,

100 BC, Canada and originated from a provenance located near Williams Lake, BC, Canada.

101 Paenibacillus polymyxa strain P2b was isolated from surface-sterilized stem tissue of a lodgepole

102 pine seedling that was naturally regenerating near Williams Lake, $\mathrm{BC}$, Canada $\left(52^{\circ} 05^{\prime} \mathrm{N}\right.$ lat.,

103 12254'W long., elevation 1300m, Sub-Boreal Pine Spruce, SBPSdc Zone) (Bal et al. 2012). P.

104 polymyxa $\mathrm{P} 2 \mathrm{~b}-2 \mathrm{R}$ is a spontaneous mutant that was derived from stain $\mathrm{P} 2 \mathrm{~b}$ grown on combined

105 carbon medium (CCM) agar amended with 200mg/L rifamycin (Bal et al. 2012). Strain P2b-2R

106 was stored at $-80{ }^{\circ} \mathrm{C}$ on CCM amended with $20 \%$ (v/v) glycerol.

107 Seed inoculation and seedling growth

108 Seedlings were grown in Ray Leach cone-tainers $(210 \mathrm{~mm}$ height $\mathrm{x} 38 \mathrm{~mm}$ diameter) that were

109 filled to $67 \%$ capacity with an autoclaved sand-Turface mixture $(69 \% \mathrm{w} / \mathrm{w}$ silica sand; $29 \%$ w/w

110 Turface; $2 \%$ w/w $\mathrm{CaCO}_{3}$ ). Two seed inoculation "levels" (i.e., inoculated with (i) live P2b-2R

111 and (ii) sterile phosphate buffered saline (PBS)) were evaluated at four soil $\mathrm{N}$ concentrations

$112\left(5.9,5.9 \times 10^{1}, 5.9 \times 10^{2}\right.$ and $5.9 \times 10^{3} \mu \mathrm{M}$, which corresponded to very low, low, medium and high 
$113 \mathrm{~N}$ treatments, respectively), resulting in eight treatment combinations. In total, 45 seedlings were

114 used in each treatment (altogether eight treatments) in this yearlong experiment. Prior to

115 inoculation, each cone-tainer was fertilized to saturation with $20 \mathrm{~mL}$ of a nutrient solution

116 (Chanway et al. 1988), which was modified by replacing $\mathrm{KNO}_{3}$ and $\mathrm{Ca}\left(\mathrm{NO}_{3}\right)_{2} \cdot 4 \mathrm{H}_{2} \mathrm{O}$ with

$117 \mathrm{Ca}\left({ }^{15} \mathrm{NO}_{3}\right)_{2}\left(5 \%{ }^{15} \mathrm{~N}\right.$ label $)$ and Sequestrene $330 \mathrm{Fe}$ with $\mathrm{Na}_{2}$ FeEDTA $(0.02 \mathrm{~g} / \mathrm{L})$. The modified

118 plant nutrient solution contained one of the four $\mathrm{N}$ concentrations described above as well as

119 (g/L): $\mathrm{KH}_{2} \mathrm{PO}_{4}, 0.14 ; \mathrm{MgSO}_{4}, 0.49 ; \mathrm{H}_{3} \mathrm{BO}_{3}, 0.001 ; \mathrm{MnCl}_{2}-4 \mathrm{H}_{2} \mathrm{O}, 0.001 ; \mathrm{ZnSO}_{4}-7 \mathrm{H}_{2} \mathrm{O}, 0.001 ;$

$120 \mathrm{CuSO}_{4}-5 \mathrm{H}_{2} \mathrm{O}, 0.0001$; and $\mathrm{NaMoO}_{4}-2 \mathrm{H}_{2} \mathrm{O}, 0.001$.

121 Lodgepole pine seeds were surface sterilized by immersion in $30 \%$ hydrogen peroxide for

12290 seconds followed by three $30 \mathrm{sec}$ rinses in sterile distilled water. After surface sterilization, ten

123 randomly selected seeds were imprinted on tryptic soy agar (TSA) and incubated at $30^{\circ} \mathrm{C}$ for two

124 days to check for surface contamination. Uncontaminated lodgepole pine seeds were then placed

125 in sterile cheesecloth bags and stratified on moist, sterile sand for five weeks at $4^{\circ} \mathrm{C}$. Ten

126 randomly selected stratified seeds were then checked for internal contamination by $P$. polymyxa

127 P2b-2R by aseptically crushing seeds and plating the resulting extracts on TSA amended with

128 200mg/L rifamycin. Plates were examined for contamination two days later. Three surface-

129 sterilized seeds were sown aseptically in each cone-tainer and covered with $5 \mathrm{~mm}$ of autoclaved

130 silica sand. Bacterial inoculum was prepared by thawing a frozen culture of strain P2b-2R,

131 streaking a loopful onto CCM agar amended with $200 \mathrm{mg} / \mathrm{L}$ rifamycin, and incubating at $30^{\circ} \mathrm{C}$

132 for two days. A 1-L flask containing 500mL of CCM broth amended with rifamycin was then

133 inoculated with a loopful of bacterial growth from the agar, secured on a rotary shaker and

134 agitated $(150 \mathrm{rpm})$ at room temperature for two days. Bacterial cells were harvested by

135 centrifugation $(3000 \times \mathrm{g} ; 30 \mathrm{~min})$, washed twice in sterile PBS (pH 7.4) and resuspended in the 
136 same buffer to a density of ca. $10^{6} \mathrm{cfu} / \mathrm{mL}$. P2b-2R-PBS suspension $(5 \mathrm{~mL})$ was then pipetted

137 into each cone-tainer designated for live P2b-2R treatment. This process was repeated using $5 \mathrm{~mL}$

138 of sterile PBS without bacteria for non-inoculated (control) cone-tainers. All cone-tainers were

139 placed in trays (98 cells) and transported to the greenhouse at the University of British Columbia,

140 Vancouver, BC, Canada. A 16-h photoperiod (6am to $10 \mathrm{pm}$ ) with an intensity of at least

$141300 \mu \mathrm{mol} / \mathrm{s} / \mathrm{m}^{2}$ was achieved with a combination of natural and artificial light in the greenhouse.

142 Greenhouse had glass walls and roof to allow the natural light to come in and artificial lighting

143 (incandescent tubes and fluorescent bulbs) was used to supplement the natural light so as to keep

144 the light intensity of at least $300 \mu \mathrm{mol} / \mathrm{s} / \mathrm{m}^{2}$ inside the greenhouse. Seedlings were watered as

145 required with tap water and thinned to the largest single germinant per cone-tainer two weeks

146 after sowing. Seedlings received $20 \mathrm{~mL}$ of modified nutrient solution containing one of the four

147 concentrations of $\mathrm{Ca}\left({ }^{15} \mathrm{NO}_{3}\right)_{2}$ once per month during the twelve-month growth trial. Tray

148 position was randomized weekly to reduce positional effects during the experiment.

\section{Rhizospheric and endophytic colonization}

150 For evaluation of rhizosphere colonization, three randomly selected seedlings from each

151 treatment were harvested destructively four, eight and twelve months after sowing. Seedlings

152 were removed from cone-tainers, and loosely adhering soil particles were removed from roots

153 with gentle shaking. Roots were then separated from shoots, placed in sterile Falcon tubes

154 (50mL) filled with 10mL of autoclaved PBS and shaken on a vortex mixer at $1000 \mathrm{rpm}$ for one

155 minute. Ten-fold serial dilutions were performed, and $100 \mu \mathrm{L}$ aliquots were then plated on CCM

156 plates amended with rifamycin $(200 \mathrm{mg} / \mathrm{L})$ and cycloheximide $(100 \mathrm{mg} / \mathrm{L})$. Plates were incubated

157 at room temperature for seven days, after which colonies were counted. Roots were washed and 
158 oven-dried at $65^{\circ} \mathrm{C}$ for two days before weighing. Rhizospheric bacterial populations were then

159 calculated as the number of cfu/g dry root.

160 For evaluation of endophytic colonization, three randomly selected seedlings from each

161 treatment were harvested destructively at the time of rhizosphere colonization sampling.

162 Seedlings were agitated $(150 \mathrm{rpm})$ in a $2-\mathrm{L}$ flask containing $800 \mathrm{~mL}$ of PBS for 20 min for

163 removal of loosely adhering growth media. Seedlings were then surface-sterilized in $1.3 \%(\mathrm{w} / \mathrm{v})$

164 sodium hypochlorite for five minutes, rinsed three times with sterile PBS, imprinted on TSA and

165 left for $24 \mathrm{~h}$ to check for surface microbial contamination. Needle, stem and root tissue samples

166 (20mg fresh weight) were then triturated separately in $1 \mathrm{~mL}$ of PBS and tissue homogenates

167 were serially diluted on CCM agar plates supplemented with 100mg/L cycloheximide or with

168 cycloheximide $(100 \mathrm{mg} / \mathrm{L})$ and rifamycin $(200 \mathrm{mg} / \mathrm{L})$. This protocol was modified for the second

169 harvest by reducing the concentration of sodium hypochlorite from $1.3 \%$ to $1.0 \%$. For the final

170 harvest, seedlings were treated with $0.6 \%$ sodium hypochlorite for seven minutes.

171 Analysis of foliar $N$ and seedling biomass

172 Nine seedlings from each treatment were harvested destructively four, eight and twelve months

173 after sowing for evaluation of seedling biomass, foliar $\mathrm{N}$ and ${ }^{15} \mathrm{~N}$ content. Root and shoot of

174 seedlings were separated and dried at $65^{\circ} \mathrm{C}$ for two days before weighing to know the biomass.

175 Needles were then removed from shoot, weighed, ground to a particle size of less than $1 \mathrm{~mm}$ and

176 mixed thoroughly. For foliar $\mathrm{N}$ analysis, a 5mg subsample of ground oven dried foliage from

177 each seedling was sent to the Stable Isotope Facility at the University of California, Davis, CA,

178 USA. Foliar $\mathrm{N}$ content and $\%{ }^{15} \mathrm{~N}$ excess were determined with an elemental analyzer interfaced 
179 with an isotope ratio mass spectrometer. The amount of fixed $\mathrm{N}$ in foliage can be estimated by 180 calculating \%Ndfa (Rennie et al. 1978) as follows:

$181 \% \mathrm{Ndfa}=\left[1-\left\{\right.\right.$ atom $\%{ }^{15} \mathrm{~N}$ excess (inoculated plant) $/ \%{ }^{15} \mathrm{~N}$ excess (non-inoculated plant) $\left.\}\right] \mathrm{x}$ $182100 \%$

\section{Statistical analyses}

184 For the seedling growth experiment, the eight treatment combinations, i.e., two inoculation levels

$185 \mathrm{x}$ four soil $\mathrm{N}$ concentrations, were arranged according to a completely randomized design. A 186 two-way analysis of variance (ANOVA) was performed using SAS 9.3 (Copyright (c) 2012, 187 SAS Institute Inc., Cary, NC, USA) to evaluate the effects of bacterial inoculation and soil N 188 concentration on growth parameters (Foliar $\mathrm{N}$ content, ${ }^{15} \mathrm{~N}$ atom percent excess, total foliar $\mathrm{N}$, 189 shoot biomass and root biomass), four, eight and twelve months after inoculation. The 190 confidence level, $\alpha$, was set to 0.05 to determine the significance of the model and treatment

191 effects. Bacterial colony counts were log transformed prior to analysis in order to meet the 192 statistical assumptions of normally distributed residuals and variance homogeneity.

\section{Results}

\section{Rhizospheric and endophytic colonization}

195 P. polymyxa $\mathrm{P} 2 \mathrm{~b}-2 \mathrm{R}$ was recovered from the rhizosphere of inoculated seedlings at each harvest.

196 Rhizosphere population densities ranged from 3.1 to $4.4 \mathrm{log}$ cfu/g dry root and did not differ 197 significantly with soil $\mathrm{N}$ concentration (Fig. 1). With the exception of those from the high $\mathrm{N}$ 198 treatment where P2b-2R densities increased over time, rhizosphere population densities tended to 
199 decline between months four and twelve (Fig. 1). P2b-2R was not recovered from surface-

200 disinfected lodgepole pine tissues until the final harvest when the modified surface-sterilization

201 protocol was used. Paenibacillus polymyxa strain P2b-2R was detected inside root and stem

202 tissues but not inside needles in twelve month-old seedlings (Fig. 2).

203 Seedling growth responses to $P 2 b-2 R$ at varying soil $N$ concentrations

204 Foliar N content (FNC) generally increased between four and eight months after sowing and 205 inoculation and then declined thereafter (Table S1). Inoculation generally had insignificant 206 effects on foliar N content during the experiment. Seedling total foliar N (TFN) was affected 207 primarily by soil $\mathrm{N}$ concentration and not by bacterial inoculation (Table S2). Seedlings from the 208 high soil $\mathrm{N}$ treatment generally accumulated more foliar $\mathrm{N}$ than those receiving lower soil $\mathrm{N}$ 209 concentrations but inoculation had no clear effect on seedling TFN. Foliar ${ }^{15} \mathrm{~N}$ atom percent

210 excess increased with increasing soil $\mathrm{N}$ concentrations (Table S3), but was unaffected by

211 inoculation. Due to lack of significant inoculation effects on ${ }^{15} \mathrm{~N}$ atom percent excess $(p>0.10)$,

$212 \%$ Ndfa was not calculated.

213 Seedlings inoculated with Paenibacillus polymyxa P2b-2R generally had less root and

214 shoot biomass compared to their respective controls four months after sowing and inoculation

215 (Table 1). Seedling growth inhibition appeared to be greatest in the low soil $\mathrm{N}$ treatment after

216 four months of inoculation, where inoculated seedlings accumulated $29.7 \%$ and $37.0 \%$ less root

217 and shoot biomass, respectively. However, this tendency was not apparent by month eight as root

218 and shoot biomass of inoculated and non-inoculated seedlings did not differ across four $\mathrm{N}$

219 treatments (Table 1) and by month twelve, inoculated seedlings from the very low $\mathrm{N}$ treatment 220 had a $52.3 \%$ and $46.4 \%$ increase in root and shoot biomass, respectively. Seedlings from the 
221 medium $\mathrm{N}$ treatment responded similarly to inoculation, but no such effects were observed at the

222 low and high soil $\mathrm{N}$ concentrations.

\section{Discussion}

224 Recovery of $P$. polymyxa $\mathrm{P} 2 \mathrm{~b}-2 \mathrm{R}$ from the rhizosphere of lodgepole pine seedlings harvested

225 four, eight and twelve months after inoculation suggests that this strain is a competent 226 rhizosphere colonizer. By the end of the twelve-month growth trial P2b-2R densities were

227 comparable to other reported studies about this bacterial strain (Anand et al. 2013; Bal and

228 Chanway 2012a). Despite the large differences in the amount of added $\mathrm{N}$ among the three lowest

229 soil $\mathrm{N}$ treatments, i.e., 10-100 fold, P2b-2R population sizes decreased over time and stabilized

230 to a density of approximately $3.1 \mathrm{log}$ cfu/g dry root, twelve months after inoculation. Such a

231 decline of bacterial population densities with seedling age has been reported for Bacillus strains

232 colonizing the rhizosphere of lodgepole pine (Holl and Chanway 1992) and spruce (Picea glauca

233 (Moench) Voss x Picea engelmannii Parry ex Engelm.) (Shishido and Chanway 2000). Since

234 root exudates are the most probable carbon source that could sustain rhizosphere-colonizing

235 microorganisms (Bais et al. 2006), the population decrease of P2b-2R may be attributed to a

236 decrease in the amount of photosynthate translocated to the root as plants age (Keith and Oades

237 1986; Domanski et al. 2001).

Endophytic P2b-2R has been isolated from stem and root tissues of lodgepole pine

239 seedlings as early as two weeks after inoculation (Anand and Chanway 2013a), however we

240 were not able to isolate P2b-2R from surface-sterilized tissues of lodgepole pine until twelve

241 months after inoculation. Unsuccessful recovery of endophytes has been observed when sodium

242 hypochlorite was used to sterilize plant samples (McInroy et al. 1996). At micro molar 
243 concentrations, sodium hypochlorite is known to significantly reduce microbial populations

244 (Nakagawara et al. 1998) and may render injured bacterial cells non-culturable by predisposing

245 them to oxidative stress (Dukan et al. 1999) and DNA damage, which can result in loss of

246 antibiotic resistance (Dukan et al. 1999; Heisiq 1996). When the surface sterilization protocol

247 was revised by reducing the concentration of sodium hypochlorite from $1.3 \%$ to $0.6 \%$,

248 endophytic P2b-2R was detected in root and stem tissues of twelve-month-old lodgepole pine

249 (Fig. 2). This reduction in concentration of sodium hypochlorite was efficient enough to kill all

250 microbes except the endophytic P2b-2R. The average endophytic population densities were

251 similar to those reported by Anand et al. (2013) and were much higher than those isolated from

252 the rhizosphere in this study, four, eight or twelve months after inoculation. This indicates that

253 the lodgepole pine interior may be a more protected habitat that allows $\mathrm{P} 2 \mathrm{~b}-2 \mathrm{R}$ to reach higher

254 population densities than in the rhizosphere.

255 The primary objective of this study was to determine if the amount of $\mathrm{N}$ fixation by

256 lodgepole pine seedlings colonized by $P$. polymyxa $\mathrm{P} 2 \mathrm{~b}-2 \mathrm{R}$ would decrease in response to

257 increasing soil $\mathrm{N}$ concentrations. However, even though a decrease in seedling foliar $\mathrm{N}$ content

258 was observed across four soil $\mathrm{N}$ treatments between months eight and twelve (Table S1)

259 indicating that lodgepole pine seedlings experienced $\mathrm{N}$ deficiency, we were unable to detect

260 significant foliar ${ }^{15} \mathrm{~N}$ dilution (hence BNF) in the assay system. In fact, twelve months after

261 inoculation, the foliar $\mathrm{N}$ content of seedlings from very low, low and medium soil $\mathrm{N}$ treatments

262 was at a level that is considered 'very severely deficient' for lodgepole pine (Ballard and Carter

263 1986). These results are not in agreement with those reported in previous studies using a glass-

264 tube plant growth and inoculation system (Bal and Chanway 2012a; Anand et al. 2013). Several

265 differences between the two seedling growth trials may have contributed to these discrepant 
266 findings. Unlike the glass-tube assay system, where $\mathrm{N}$-fertilizer was applied once, i.e., at the time

267 of sowing and inoculation, monthly application of $\mathrm{N}$-containing fertilizer was used in our

268 experiment to reduce leaching of nitrate from the bottom of cone-tainers. If our inoculated

269 seedlings were deriving $\mathrm{N}$ from the atmosphere, the frequency of $\mathrm{N}$-fertilization may have

270 obscured our ability to detect ${ }^{15} \mathrm{~N}$ foliar dilution. In addition, the larger rooting volume provided

271 by cone-tainers might have resulted in enhanced soil $\mathrm{N}$ uptake, which is known to suppress BNF

272 (Shrestha and Ladha 1996). There is a possibility that this bacterial strain might have infected the

273 rhizosphere and internal tissues but was not able to form a mutualistic relationship with the plant

274 and fix N. A possible reason for this could be that, since the $\mathrm{N}$-fertilizer was applied every

275 month, conditions were not optimum (N-limited) for bacteria to trigger $\mathrm{N}$-fixation mechanism

276 (Bal and Chanway 2012a, b).

Seedling biomass reduction by $\mathrm{P} 2 \mathrm{~b}-2 \mathrm{R}$ inoculation in lodgepole pine seedlings was

278 previously reported in a study (Bal and Chanway 2012a). In our cone-tainer system, the

279 inhibitory effects on seedling biomass were also observed four months after inoculation (Table

280 1). Given that $\mathrm{N}$-fixation is an energetically expensive process, poorer performance of lodgepole

281 pine seedlings inoculated with $\mathrm{P} 2 \mathrm{~b}-2 \mathrm{R}$ has been suggested to result from the maintenance of

282 BNF at the expense of plant-derived carbon substrates (Bal and Chanway 2012a). However, due

283 to the insignificant inoculation effects on foliar ${ }^{15} \mathrm{~N}$ dilution (Table S3), it is not possible to relate

284 seedling biomass responses to BNF. Nonetheless, considering that inoculated seedlings in all soil

$285 \mathrm{~N}$ treatments had lower root and shoot biomass than their controls after four and eight months of 286 inoculation (Table 1), it could be hypothesized that P2b-2R can act as a parasite (at least 287 temporarily), depending on lodgepole pine for carbon substrates without providing fixed $\mathrm{N}$ in 288 return. Since low soil $\mathrm{N}$ availability can limit a plant's ability to produce photosynthate, the 
289 greater magnitude of biomass reduction was observed at the very low and low $\mathrm{N}$ levels at the

290 first and second harvest (Table 1). Our results suggest that lodgepole pine seedling growth

291 inhibition by $\mathrm{P} 2 \mathrm{~b}-2 \mathrm{R}$ can occur at a wide range of soil $\mathrm{N}$ concentrations and characterizes early

292 stages of the lodgepole pine $\mathrm{x}$ P2b-2R interaction. The pronounced seedling biomass

293 enhancement by $\mathrm{P} 2 \mathrm{~b}-2 \mathrm{R}$ that was observed twelve months after inoculation for very low $\mathrm{N}$

294 treatment (Table 1) is in agreement with previous results (Anand et al. 2013), and supports the

295 hypothesis that a mutualism exists between lodgepole pine and this bacterium. Biomass

296 accumulation due to bacterial inoculation was more pronounced in the very low $\mathrm{N}$ treatment,

297 since inoculated seedlings from the very low $\mathrm{N}$ treatment had a $52.3 \%$ and $46.4 \%$ increase in

298 root and shoot biomass, respectively. This is in agreement with the claim reported in previous

299 studies about this bacterial strain (Bal and Chanway 2012a, b; Anand and Chanway 2013b), that

300 inoculated seedlings trigger $\mathrm{N}$ fixation process when cultured in $\mathrm{N}$-limited conditions.

301 Biologically fixed $\mathrm{N}$ is stored in the plant thus increasing the biomass. Therefore, our data

302 support the hypothesis that seedling growth promotion by $\mathrm{P} 2 \mathrm{~b}-2 \mathrm{R}$ is more pronounced at the low

303 soil N concentrations. Seedlings growth inhibition was observed at high soil N treatment level

304 during this whole year-long growth trail, supporting the hypothesis (Anand et al. 2013) that plant

305 growth promotion by P2b-2R occurs in N-limited conditions. Anand et al. (2013) suggested that

306 P2b-2R enhanced performance of lodgepole pine seedlings through BNF. However, the same

307 bacterial strain in our experiment was able to stimulate lodgepole pine biomass without affecting

308 foliar ${ }^{15} \mathrm{~N}$ atom \% excess (Table S3), suggesting that P2b-2R might promote the growth of our

309 lodgepole pine seedlings without providing appreciable amounts of fixed N. It is well known that

310 other $P$. polymyxa strains can enhance plant performance by producing phytohormones 
311 (Chanway 2008), but the ability of P2b-2R to synthesize plant growth regulators such as auxins

312 and cytokinins requires further assessment.

313 To conclude, we observed that P2b-2R acts as a parasite by supressing the growth of

314 lodgepole pine during the initial stages of plant growth. But once established inside the plant, it

315 forms a mutualistic relation by taking carbon from the plant and promoting plant growth in

316 return at very low and medium $\mathrm{N}$ concentrations. It was also observed that this bacterial strain

317 wasn't able to fix $\mathrm{N}$ from the atmosphere but was still able to stimulate plant growth, likely

318 through other means.

319 Acknowledgement

320 This work was supported through funding from the Natural Sciences and Engineering Research

321 Council of Canada (NSERC) Discovery Grant (RGPIN 41832-13) to Dr. Chris P Chanway. 


\section{References}

323

324

325

326

327

328

329

330

331

332

333

334

335

336

337

338

339

340

341

342

343

344

345

346

347

348

349

350

351

352

353

354

Abellan, I.P., Urguiza, R.D.A., Valadier, M.H., and Champigny, M.L. 1994. Short-term effect of nitrate on carbon metabolism of two sugarcane cultivars differing in their biomass production. Phytochemistry 36(4): 819-823. doi:10.1016/S0031-9422(00)90444-8.

Anand, R., and Chanway, C.P. 2013a. Detection of GFP-labeled Paenibacillus polymyxa in autofluorescing pine seedling tissues. Biol. Fertil. Soils 49(1): 111-118. doi:10.1007/s00374-0120727-9.

Anand, R., and Chanway, C. 2013b. $\mathrm{N}_{2}$-fixation and growth promotion in cedar colonized by an endophytic strain of Paenibacillus polymyxa. Biol. Fertil. Soils 49(2): 235-239. doi:10.1007/s00374-012-0735-9.

Anand, R., and Chanway, C.P. 2013c. nif gene sequence and arrangement in the endophytic diazotroph Paenibacillus polymyxa strain P2b-2R. Biol. Fertil. Soils 49(7): 965-970. doi:10.1007/s00374-013-0793-7.

Anand, R., Grayston, S., and Chanway, C.P. 2013. $\mathrm{N}_{2}$-fixation and seedling growth promotion of lodgepole pine by endophytic Paenibacillus polymyxa. Microb. Ecol. 66(2): 369-374. doi:10.1007/s00248-013-0196-1.

Ash, C., Priest, F.G., and Collins, M.D. 1993. Molecular identification of rRNA group 3 bacilli (Ash, Farrow, Wallbanks and Collins) using a PCR probe test. A. van. Leeuw. J. Microb. 64(34): 253-260. doi:10.1007/BF00873085.

Azevedo, J.L., Maccheroni Jr, W., Pereira, J.O., and Araújo, W.L. 2000. Endophytic microorganisms: a review on insect control and recent advances on tropical plants. Electron. J. Biotechnol. 3(1):40-65. doi:10.2225/vol3-issue1-fulltext-4.

Bais, H.P., Weir, T.L., Perry, L.G., Gilroy, S., and Vivanco, J.M. 2006. The role of root exudates in rhizosphere interactions with plants and other organisms. Annu. Rev. Plant Biol. 57: 233-266. doi:10.1146/annurev.arplant.57.032905.105159.

Bal, A., Anand, R., Berge, O., and Chanway, C.P. 2012. Isolation and identification of diazotrophic bacteria from internal tissues of Pinus contorta and Thuja plicata. Can. J. For. Res. 42(4):807-813. doi:10.1139/x2012-023.

Bal, A., and Chanway, C.P. 2012a. Evidence of nitrogen fixation in lodgepole pine inoculated with diazotrophic Paenibacillus polymyxa. Botany 90(9): 891-896. doi:10.1139/b2012-044.

Bal, A., and Chanway, C.P. 2012 b. ${ }^{15} \mathrm{~N}$ foliar dilution of western red cedar in response to seed inoculation with diazotrophic Paenibacillus polymyxa. Biol. Fertil. Soils 48(8): 967-971. doi:10.1007/s00374-012-0699-9. 
355 Ballard, T.M., and Carter, R.E. 1986. Evaluating forest stand nutrient status. Land Management Report Number 20, ISSN 0702-9861. BC Ministry of Forests, Victoria, Canada. pp. 33-34.

357 Cacciari, I., Del Gallo, M., Ippoliti, S., Lippi, D., Pietrosanti, T., and Pietrosanti, W. 1986.

358 Growth and survival of Azospirillum brasilense and Arthrobacter giacomelloi in binary continuous culture. Plant Soil 90(1/3): 107-116. doi:10.1007/BF02277390.

360 Chanway, C.P. 2008. Plant growth promotion by Bacillus and relatives. In Applications and Systematics of Bacillus and Relatives. Edited by R. Berkeley, M. Heyndrickx, N. Logan and P. de Vos. Blackwell Science Ltd, Oxford, UK. pp. 219-235.

363 Chanway, C.P., Nelson, L.M., and Holl, F.B. 1988. Cultivar-specific growth promotion of spring wheat (Triticum aestivum L.) by coexistent Bacillus species. Can. J. Microbiol. 34(7): 925-929. doi:10.1139/m88-164.

366 Chapman, W.K., and Paul, L. 2012. Evidence that northern pioneering pines with tuberculate mycorrhizae are unaffected by varying soil nitrogen levels. Microb. Ecol. 64(4): 964-972. doi:10.1007/s00248-012-0076-0. and Wasson, M.F. 1999. Global patterns of terrestrial biological nitrogen $\left(\mathrm{N}_{2}\right)$ fixation in natural ecosystems. Global Biogeochem. Cycles 13(2): 623-645. doi:10.1029/1999GB900014.

372 Cocking, E. 2003. Endophytic colonization of plant roots by nitrogen-fixing bacteria. Plant Soil 373 252(1):169-175. doi:10.1023/A:1024106605806.

Dobereiner, J., Baldani, V.L.D., Reis, and V.M. 1995. Endophytic occurrence of diazotrophic bacteria in non-leguminous crops. In Azospirillum VI and related microorganisms. Edited by I. Fendrik, M. del Gallo, J. Vanderleyden and M. de Zamarocy. Springer Verlag, Berlin Heidelberg

377 Germany. pp. 3-14. rhizosphere of ryegrass (Lolium perenne). J. Soil Sci. Plant Nutr. 164(4): 381-387. doi:10.1002/1522-2624(200108)164:4<381::AID-JPLN381>3.0.CO;2-5.

381 Dixon, R., and Kahn, D. 2004. Genetic regulation of biological nitrogen fixation. Nat. Rev.

382 Microbiol. 2(8): 621-631. doi:10.1038/nrmicro954.

383 Dukan, S., Belkin, S., and Touati, D. 1999. Reactive oxygen species are partially involved in the 384 bacteriocidal action of hypochlorous acid. Arch. Biochem. Biophys. 367(2): 311-316. 385 doi:10.1006/abbi.1999.1265.

386 Fuentes-Ramirez, L.E., Caballero-Mellado, J., Supulveda, J., and Martinez-Romero, E. 1999. 387 Colonization of sugarcane by Acetobacter diazotrophicus is inhibited by high $\mathrm{N}$-fertilization. 388 FEMS Microbiol. Ecol. 29(2): 117-128. doi:10.1016/S0168-6496(98)00125-1. 
Gehring, C., Vlek, P.L.G., de Souza, L.A.G., and Denich, M. 2005. Biological nitrogen fixation in secondary regrowth and mature rainforest of central Amazonia. Agric. Ecosyst. Environ.

391 111(1): 237-252. doi:10.1016/j.agee.2005.06.009.

392 Hallmann, J., Quadt-Hallmann, A., Mahaffee, W.F., and Kloepper, J.W. 1997. Bacterial endophytes in agricultural crops. Can. J. Microbiol. 43(10): 895-914. doi:10.1139/m97-131.

394 Heisiq, P. 1996. Genetic evidence for a role of parC mutations in development of high-level fluoroquinolone resistance in Escherichia coli. Antimicrob. Agents Chemother. 40(4): 879-885.

396 Holl, F.B., and Chanway, C.P. 1992. Rhizosphere colonization and seedling growth promotion of 397 lodgepole pine by Bacillus polymyxa. Can. J. Microbiol. 38(4): 303-308. doi:10.1139/m92-050.

Keith, H., and Oades, J.M. 1986. Input of carbon to soil from wheat plants. Soil Biol. Biochem. 18(4): 445-449. doi:10.1016/0038-0717(86)90051-9.

400 Mahendrappa, M.K., and Salonius, P.O. 1982. Nutrient dynamics and growth response in a 401 fertilized black spruce stand. Soil Sci. Soc. Am. J. 46(1): 127-133.

402 doi:10.2136/sssaj1982.03615995004600010024x.

403 Malik, K.A., Bilal, R., Mehnaz, S., Rasul, G., Mirza, M.S., and Ali, S. 1997. Association of 404 nitrogen-fixing, plant-growth-promoting rhizobacteria (PGPR) with kallar grass and rice. Plant 405 Soil 194(1): 37-44. doi:10.1023/A:1004295714181.

406 McInroy, J.A., Musson, G., Wei, G., and Kloepper, J.W. 1996. Masking of antibiotic-resistance 407 upon recovery of endophytic bacteria. Plant Soil 186(2): 213-218. doi:10.1007/BF02415516

408 Munoz-Rojas, J., and Caballero-Mellado, J. 2003. Population dynamics of Gluconacetobacter diazotrophicus in sugarcane cultivars and its effect on plant growth. Microb. Ecol. 46(4): 454410 464. doi:10.1007/s00248-003-0110-3.

411 Nakagawara, S., Goto, T., Nara, M., Ozawa, Y., Hotta, K., and Arata, Y. 1998. Spectroscopic characterization and the $\mathrm{pH}$ dependence of bactericidal activity of the aqueous chlorine solution. 413 Anal. Sci. 14(4): 691-698. doi:10.2116/analsci.14.691.

414 Newton, W.E. 2007. Physiology, biochemistry, and molecular biology of nitrogen fixation. In 415 Biology of the Nitrogen Cycle. Edited by H. Bothe, S.J. Ferguson and W.E. Newton. Elsevier, 416 The Netherlands. pp. 109-129.

417 Padda, K.P., Puri, A., and Chanway, C.P. 2016. Effect of GFP tagging of Paenibacillus 418 polymyxa $\mathrm{P} 2 \mathrm{~b}-2 \mathrm{R}$ on its ability to promote growth of canola and tomato seedlings. Biol. Fertil. 419 Soils. 52(3): 377-387. doi:10.1007/s00374-015-1083-3.

420 Postgate, J.R. 1998. Nitrogen fixation. Cambridge University Press, Cambridge, UK. 
421 Puri, A., Padda, K.P., and Chanway, C.P. 2015. Can a diazotrophic endophyte originally isolated 422 from lodgepole pine colonize an agricultural crop (corn) and promote its growth? Soil Biol.

423 Biochem. 89: 210-216. doi:10.1016/j.soilbio.2015.07.012.

424 Puri, A., Padda, K.P., and Chanway, C.P. 2016a. Evidence of nitrogen fixation and growth 425 promotion in canola (Brassica napus L.) by an endophytic diazotroph Paenibacillus polymyxa 426 P2b-2R. Biol. Fertil. Soils. 52(1): 119-125. doi:10.1007/s00374-015-1051-y.

427 Puri, A., Padda, K.P., and Chanway, C.P. 2016b. Seedling growth promotion and nitrogen 428 fixation by a bacterial endophyte Paenibacillus polymyxa $\mathrm{P} 2 \mathrm{~b}-2 \mathrm{R}$ and its GFP derivative in corn 429 in a long-term trial. Symbiosis. doi:10.1007/s13199-016-0385-z.

430 Reed, H.E., and Martiny, J.B.H. 2007. Testing the functional significance of microbial 431 composition in natural communities. FEMS Microbiol. Ecol. 62(2): 161-170.

432 doi:10.1111/j.1574-6941.2007.00386.x.

433 Rennie, R.J., Fried, M., and Rennie, D.A. 1978. Concepts of ${ }^{15} \mathrm{~N}$ usage in dinitrogen fixation 434 studies. In Isotopes in biological dinitrogen fixation. International Atomic Energy Agency, 435 Vienna, Austria. pp. 107-131.

436 Shishido, M., and Chanway, C.P. 2000. Colonization and growth promotion of outplanted spruce 437 seedlings pre-inoculated with plant growth-promoting rhizobacteria in the greenhouse. Can. J. 438 For. Res. 30(6): 845-854. doi:10.1139/cjfr-30-6-845.

439 Shrestha, R.K., and Ladha, J.K. 1996. Genotypic variation in promotion of rice nitrogen fixation 440 as determined by nitrogen ${ }^{15} \mathrm{~N}$ dilution. Soil Sci. Soc. Am. J. 60(6): 1815-1821.

441 doi:10.2136/sssaj1996.03615995006000060029x.

442 Wang, L., Zhang, L., Liu, Z., Zhao, D., Liu, X., Zhang, B., ... and Li, J. 2013. A minimal 443 nitrogen fixation gene cluster from Paenibacillus sp. wly78 enables expression of active 444 nitrogenase in Escherichia coli. PLoS Genet. 9(10): e1003865. 445 doi:10.1371/journal.pgen.1003865. 
446 Table 1 Seedling biomass ( $\mathrm{mg} \pm$ standard error; $\mathrm{n}=9$ ) of lodgepole pine seedlings inoculated with $P$. polymyxa $\mathrm{P} 2 \mathrm{~b}-2 \mathrm{R}$ and

447 phosphate-buffered saline (control) measured four, eight and twelve months after inoculation at different soil $\mathrm{N}$ treatments

\begin{tabular}{|c|c|c|c|c|c|c|c|}
\hline \multirow{3}{*}{$\mathbf{N}$ treatment } & \multirow{3}{*}{ Inoculation } & \multicolumn{6}{|c|}{ Months after sowing } \\
\hline & & \multicolumn{2}{|c|}{4} & \multicolumn{2}{|c|}{8} & \multicolumn{2}{|c|}{12} \\
\hline & & Root & Shoot & Root & Shoot & Root & Shoot \\
\hline \multirow{2}{*}{ Very Low } & P2b-2R & $16.1 \pm 2.34$ & $23.1 \pm 2.43$ & $53.3 \pm 9.60$ & $39.1 \pm 9.71$ & $143 \pm 19.8^{*}$ & $100 \pm 14.0^{*}$ \\
\hline & Control & $19.0 \pm 1.23$ & $24.0 \pm 2.41$ & $46.5 \pm 5.12$ & $35.1 \pm 2.81$ & $94.1 \pm 13.4$ & $68.8 \pm 8.62$ \\
\hline \multirow{2}{*}{ Low } & $\mathrm{P} 2 \mathrm{~b}-2 \mathrm{R}$ & $16.1 \pm 2.55$ & $16.9 \pm 1.31 *$ & $39.8 \pm 7.93$ & $38.5 \pm 4.54$ & $139 \pm 18.6$ & $116 \pm 11.4$ \\
\hline & Control & $22.8 \pm 4.13$ & $26.9 \pm 3.50$ & $42.2 \pm 11.0$ & $31.4 \pm 3.33$ & $148 \pm 24.4$ & $107 \pm 13.0$ \\
\hline \multirow{2}{*}{ Medium } & $\mathrm{P} 2 \mathrm{~b}-2 \mathrm{R}$ & $22.9 \pm 2.42$ & $22.2 \pm 1.52$ & $48.2 \pm 12.8$ & $40.3 \pm 6.14$ & $184 \pm 27.9 *$ & $148 \pm 19.4^{*}$ \\
\hline & Control & $25.1 \pm 3.33$ & $24.8 \pm 2.84$ & $57.2 \pm 8.23$ & $41.2 \pm 6.72$ & $120 \pm 23.9$ & $102 \pm 15.3$ \\
\hline \multirow{2}{*}{ High } & $\mathrm{P} 2 \mathrm{~b}-2 \mathrm{R}$ & $36.4 \pm 4.63$ & $35.7 \pm 2.12$ & $84.4 \pm 12.3$ & $60.8 \pm 4.41$ & $195 \pm 65.2$ & $200 \pm 46.3$ \\
\hline & Control & $41.9 \pm 6.34$ & $36.8 \pm 2.61$ & $67.8 \pm 11.9$ & $64.4 \pm 11.8$ & $196 \pm 62.4$ & $216 \pm 45.6$ \\
\hline
\end{tabular}

$448 * \mathrm{P}<0.05$ (significantly different from control). Student's t-test was used to determine the significant difference between two 449 inoculation treatments. 


\section{$450 \quad$ Figure Legends}

451 Fig. 1 Rhizospheric population size of $P$. polymyxa $\mathrm{P} 2 \mathrm{~b}-2 \mathrm{R}$ in lodgepole pine seedlings 452 evaluated four, eight and twelve months after inoculation at different soil $\mathrm{N}$ treatments (very low, 453 low, medium and high). Error bars represent standard error of the mean $(n=3)$.

454 Fig. 2 Endophytic population size of $P$. polymyxa P2b-2R in lodgepole pine seedlings evaluated 455 twelve months after inoculation at different soil $\mathrm{N}$ treatments (very low, low, medium and high). 456 Error bars represent standard error of the mean $(n=3)$. 
457 Fig. 1

458

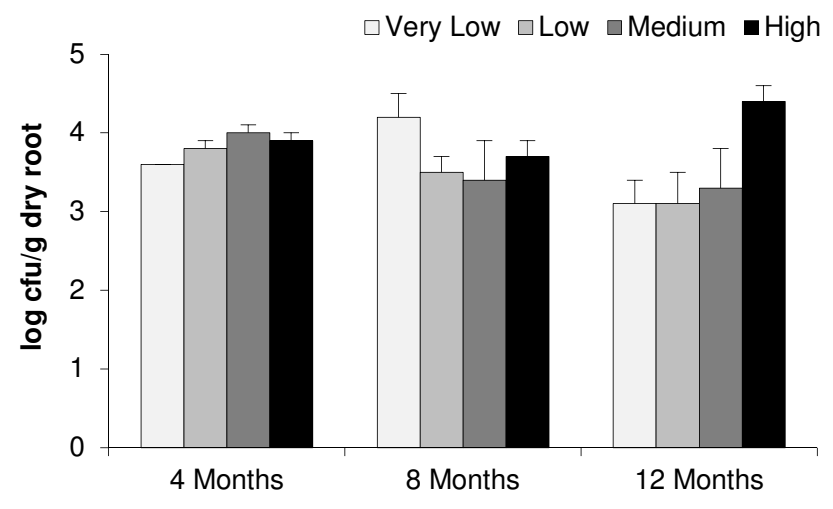


459 Fig. 2

460

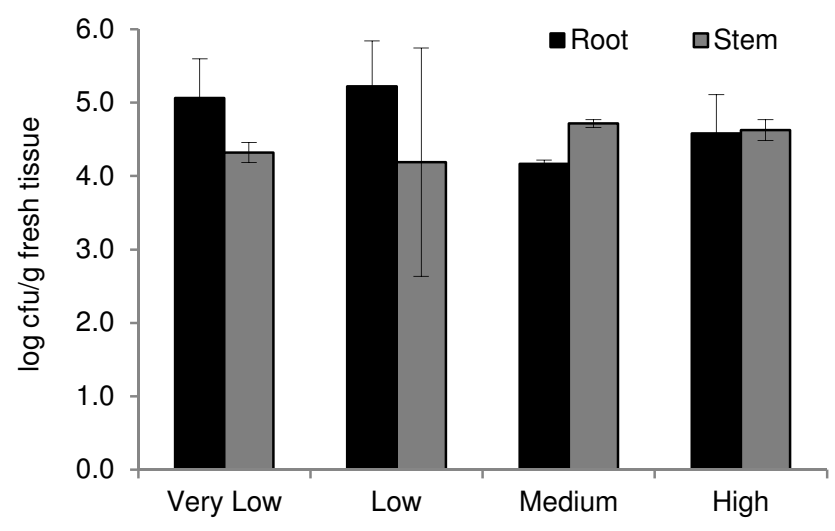


Supplementary material: Effects of Paenibacillus polymyxa inoculation and different soil nitrogen treatments on lodgepole pine seedling growth

Henry Yang, Akshit Puri, Chris P Chanway and Kiran Preet Padda

Contents: Supplementary Tables S1, S2, S3 
Table S1 Foliar N content (percentage $w / w \pm$ standard error; $n=9$ ) of lodgepole pine seedlings inoculated with P. polymyxa $\mathrm{P} 2 \mathrm{~b}-2 \mathrm{R}$ and phosphate-buffered saline (control) measured four, eight and twelve months after inoculation

\section{Months after sowing}

\begin{tabular}{ccccc} 
N treatment & Inoculation & $\mathbf{4}$ & $\mathbf{8}$ & $\mathbf{1 2}$ \\
\cline { 3 - 4 } & & & & $1.23 \pm 0.78$ \\
Very Low & P2b-2R & $0.87 \pm 0.96$ & $0.58 \pm 0.74$ \\
Low & Control & $0.72 \pm 0.99$ & $1.23 \pm 0.13$ & $0.71 \pm 0.13$ \\
& P2b-2R & $0.89 \pm 0.96$ & $1.09 \pm 0.89$ & $0.57 \pm 0.87$ \\
Medium & Control & $0.90 \pm 0.12$ & $1.19 \pm 0.95$ & $0.68 \pm 0.01$ \\
& P2b-2R & $1.02 \pm 0.97$ & $1.31 \pm 0.12$ & $0.73 \pm 0.12$ \\
High & Control & $1.00 \pm 0.14$ & $1.29 \pm 0.95$ & $0.67 \pm 0.97$ \\
& P2b-2R & $1.30 \pm 0.96$ & $1.63 \pm 0.14$ & $1.12 \pm 0.12$ \\
& Control & $1.32 \pm 0.13$ & $1.53 \pm 0.83$ & $1.14 \pm 0.93$ \\
\hline
\end{tabular}


Table S2 Total foliar N (mg \pm standard error; $n=9)$ of lodgepole pine seedlings inoculated with P. polymyxa $\mathrm{P} 2 \mathrm{~b}-2 \mathrm{R}$ and phosphate-buffered saline (control) measured four, eight and twelve months after inoculation

\begin{tabular}{ccccc}
\hline \multirow{2}{*}{ N treatment } & Inoculation & \multicolumn{3}{c}{ Months after sowing } \\
\cline { 3 - 5 } & & $\mathbf{4}$ & $\mathbf{8}$ & $\mathbf{1 2}$ \\
\hline Very Low & P2b-2R & $0.21 \pm 0.01$ & $0.31 \pm 0.11$ & $0.49 \pm 0.11$ \\
& Control & $0.11 \pm 0.01$ & $0.30 \pm 0.13$ & $0.53 \pm 0.00$ \\
Low & P2b-2R & $0.75 \pm 0.02$ & $0.33 \pm 0.01$ & $0.70 \pm 0.07$ \\
Medium & Control & $0.19 \pm 0.01$ & $0.34 \pm 0.00$ & $0.72 \pm 0.11$ \\
& P2b-2R & $0.22 \pm 0.01$ & $0.44 \pm 0.09$ & $0.90 \pm 0.13$ \\
High & Control & $0.24 \pm 0.04$ & $0.39 \pm 0.12$ & $0.73 \pm 0.98$ \\
& P2b-2R & $0.32 \pm 0.00$ & $0.73 \pm 0.08$ & $1.90 \pm 0.32$ \\
& Control & $0.28 \pm 0.03$ & $0.74 \pm 0.17$ & $2.11 \pm 0.33$ \\
\hline
\end{tabular}


Table S3 Foliar ${ }^{15} \mathrm{~N}$ atom percent excess $(\% \pm$ standard error; $\mathrm{n}=9)$ of lodgepole pine seedlings inoculated with P. polymyxa P2b-2R and phosphate-buffered saline (control) measured four, eight and twelve months after inoculation

\section{Months after sowing}

\begin{tabular}{ccccc} 
N treatment & Inoculation & $\mathbf{4}$ & $\mathbf{8}$ & $\mathbf{1 2}$ \\
\cline { 3 - 5 } & P2b-2R & $6.02 \pm 2.00$ & $31.2 \pm 5.70$ & $34.0 \pm 3.44$ \\
Very Low & Control & $3.87 \pm 1.29$ & $22.2 \pm 4.22$ & $32.6 \pm 4.62$ \\
Low & P2b-2R & $159 \pm 97.7$ & $237 \pm 24.7$ & $346 \pm 40.5$ \\
& Control & $72.2 \pm 18.2$ & $187 \pm 20.5$ & $326 \pm 20.1$ \\
Medium & P2b-2R & $1019 \pm 140$ & $2096 \pm 266$ & $3068 \pm 160$ \\
& Control & $925 \pm 83.8$ & $2262 \pm 199$ & $3046 \pm 184$ \\
High & P2b-2R & $4971 \pm 245$ & $7247 \pm 406$ & $8337 \pm 258$ \\
& Control & $5114 \pm 297$ & $6892 \pm 378$ & $8308 \pm 249$ \\
\hline
\end{tabular}

